\title{
PIRAMIS ÉS PÁLMA, VALAMINT KEMPLER FÉLE TESZT ALKALMAZÁSA NYELVFEJLŐDÉSI ZAVARRAL KÜZDÓ GYERMEKEKNÉL
}

\author{
Juhász Anikó, Fodorné F. Rita
}

\begin{abstract}
Absztrakt
A beszéd- és nyelvfejlődési zavar jelenségköre korántsem szűkíthető a beszéd-, illetve nyelvi képességek elmaradására. A nyelv elsajátításának biológiai és pszichés feltételei mellett társadalmi és szociokulturális követelmény az optimálisan beszélő környezet, a megfelelő mennyiségű és minőségü beszédminta. Célkitűzés: Célunk annak felderítése volt, hogy a Piramis és Pálma, valamint a Kempler-féle tesztek az eredeti célcsoportjuk (afázia, vizuális agnózia, Alzheimer-kór mint szemantikus emlékezeti deficit) vizsgálata mellett alkalmasak-e a 8-12 éves korú gyermekek vizsgálatára. Nemcsak a fejlődési diszlexiás gyermekek teljesítményét hasonlítottuk össze a kontroll csoport tagjaival, hanem a szociálisan hátrányos helyzetü tanulók eredményeit is elemeztük, csoportonkénti, életkori és tesztfeladatonkénti összehasonlítást is végeztünk. A statisztikai próbák kimutatták, hogy nincs szignifikáns különbség a fejlődési diszlexiások és a szociálisan hátrányos helyzetúek e két tesztben elért teljesítménye terén. A fejlődési diszlexiások és a kontroll csoport eredményei viszont szignifikánsan eltértek. A szociálisan hátrányos helyzetü gyermekek és a kontroll csoport paramétereiben szintén szignifikáns eltérés mutatkozott.

A kutatás eredményei alátámasztják, hogy a két teszt alkalmas gyermekek vizsgálatára, mivel jelzi a nyelvi fejlődés problémáit. A széles körben használt és ismert intelligenciamérő, 90 perc időterjedelmű tesztbattériát, a WISC-IV-et helyettesíthetnénk a Piramis és Pálma, valamint a Kempler-féle teszttel.
\end{abstract}

Kulcsszavak: a nyelv és a beszéd tipikus fejlődéstől való eltérései • hátrányos környezet • korlátozott nyelvi kód • fejlődési diszlexia • Piramis és Pálma Teszt • Kempler teszt

\begin{abstract}
Phenomena of verbal and language developmental disorder can by no means be narrowed to the deficit of verbal and language abilities. Besides the biological and psychological conditions of language acquisition, the optimal language environment, the quality and the quantity of the language sample are also important sociocultural requirements. Objectives: Our study focused on the question whether the Pyramid and Palm Trees and Kempler Comprehension tasks are suitable for examination of children between the age of 8-12. The original target group of the test are patients with aphasia, visual agnosia, Alzheimer's disease and semantic memory deficit. Not only the performance of children with developmental dyslexia were compared to a control group, but also socially disadvantaged students were examined. Comparisons between groups, agegroups and test items were made. Statistical tests proved that there were no significant differences between performance of the developmental dyslexia group and the socially disadvantaged group. However a significant difference was found between results of the control and the dyslexia group as well as the socially disadvantaged group. Results of
\end{abstract}


the present research prove that the two tasks are suitable for measuring problems of language development among children. The use of the commonly used intelligence test (WISC-IV), taking 90 minutes could therefore be substituted with the Pyramid and Palm Trees test and the Kempler Comprehension task

Keywords: disorders of verbal and language development - disadvantaged environment - limited language code - developmental dyslexia - Pyramid and Palm Trees Test Kempler comprehension task

\section{ELMÉLETI HÁTTÉR}

Nyelvi kompetenciáról beszél Fehérné (1998)², ha a felhasználó maga rendelkezik az általa használt nyelv jeleinek alkalmazásáról, szabályrendszeréről, és megfelelően bír a nyelvtani szabályok használatával. Mi történik azonban olyankor, ha a feltételek nem ilyen egyértelmúen adottak?

Azok a gyermekek, akiknek nyelvi képessége, elmarad az életkoruktól elvárhatótól, hátrányba kerülnek a pragmatikai szabályok felismerésében és alkalmazásában. Szélsőséges esetben akár társadalmi beilleszkedési problémákhoz is vezethet, pl. elszigetelődnek kortársaiktól, ezáltal hamarabb válnak magányossá, marginális helyzetbe kerülnek, deviáns viselkedésformát mutatnak, magatartásuk szélsőséges formát ölt, világít rá Fehérné (1998) ${ }^{\text {uo }}$.

A nyelvi kompetencia sérülésének hátterében meghúzódó okot Gósy (2009)² az intenzív környezeti zajt véli, amelynek következménye az akusztikus alakháttér megkülönböztetésének nehézsége. Minekután ma már négyszer gyorsabban beszélünk, mint 30 vagy akár 40 évvel ezelőtt, az agyi akusztikus feldolgozás erőteljesen érintett.

Pléh (1989) ${ }^{3}$ leírja, hogy a nyelvi zavarok beszéden keresztül ismerhetők fel. A nyelvi elmaradások a primer folyamatok sérülésének függvénye a kommunikáció és a nyelvelsajátítás során, mondja Fehérné (2000)4. Az 1. típusba tartozóknál a korai kommunikációs kompetencia területén lép fel a zavar, tehát korán manifesztálódik a probléma. A 2. típusúk esetében a zavar egyéves kor körül jelentkezik, s a szimbólumképzés területén jön létre. A hátterében kognitív okok húzódnak meg. Ez egyben a közlő - funkció deficitjét is magában rejti. A 3. típusba sorolható a hároméves kor körül fellépő deficit, amelyet a neurolingvisztikai folyamatok terén fellépő zavar okozza.

\footnotetext{
Fehérné Kovács Zsuzsanna: Nyelvi képességek és a tanulási zavar, Beszédgyógyítás, 1. sz., 1998, 38-41.

2 Gósy Mária: Gyermekek anyanyelvi kompetenciájáról, Gyógypedagógiai Szemle, 2-3. sz., 2009

3 Pléh Csaba: A mondatmegértés és a nyelvi szerkezet összefüggései a magyarban,

Nyelvtudományi Közlemények, 90/1-2. sz., 1989, 1-19., 19-45.

4 Fehérné Kovács Zsuzsanna: A nyelvi fejlődés zavaráról új megközelítésben, A pedagógus személyisége, Országos Szakmai Konferencia, VI. Soproni Logopédiai és Pedagógiai Napok, 2000, 96-104.
} 
Logopédusként a verbalitásra fókuszálunk, holott a nonverbális kommunikáció legalább ugyanennyire fontos. A pszichológusok a gyermek képességeinek mérése során előtérbe helyezik a Wechsler-típusú intelligenciamérő eljárásokat, pl. a Wechsler Intelligence Scale for Children - Fourth Edition-t (WISC-IV). Kutatásunk arra a kérdésre irányul, hogy ezt a széles körben használt és ismert tesztbattériát, amelynek felvétele mintegy 90 percet igényel, helyettesíthetnénk-e két másik módszerrel, a Piramis és Pálma, valamint a Kempler-féle teszttel. nonverbális deficitek a nyelvi tünetekért is felelősek lehetnek, így a nonverbális sajátosságok tanulmányozása útján közelebb juthatunk a nyelvelsajátításban szerepet játszó specifikus kognitív képességek beazonosításához.

További célként nemcsak a fejlődési diszlexiás gyermekek, hanem hátrányos helyzetủ tanulók teljesítményét is össze kívántuk hasonlítani egy kontrollcsoport tagjaival. Mindezt annak reményében tettük, hogy eredményeink kiindulási pontként szolgálhassanak a két eljárás magyar sztenderdjéhez.

\subsection{A nyelv és a beszéd a tipikus fejlődéstől való eltérései}

„Minden olyan esetben, amikor a nyelv/beszéd elsajátítása, kompetenciája, használata megnyilvánulásának bármely formája (írott nyelv, beszélt nyelv, jelnyelv) eltér a többségi nyelvhasználókétól, a tipikustól való minőségi/mennyiségi eltérés függvényében (időbeliség, kiterjedtség, tüneti szerveződés, kóroktan, súlyosság) beszélhetünk beszédsérülésről, beszéd - és nyelvi elmaradásról, beszéd - és nyelvi zavarról, beszédbeli akadályozottságról, beszédfogyatékosságról” (Fehérné, 2009. 39. o.)5. A nyelvi zavar ezen értelmezése a nyelvi elemek és szabályok ismeretének, illetve alkalmazásának zavarát, hiányosságát veszi górcső alá. A beszéd- és nyelvfejlődés késhet, akadályozottá válhat, elakadhat. A háttérben biológiai, pszichés vagy környezeti okok állnak. Amennyiben a deficiteket a szakemberek nem tárják fel, nem szüntetik meg, akkor a nyelvi zavar a súlyosságtól függően gátjává válik a kogníciónak, gondolkodásnak, az ismeretek magasabb szintű elsajátításának, hívja fel rá a figyelmünket Fehérné (2009).

A különféle eredetű eltérések vagy károsodások következményeként megjelenő nyelvi és beszédzavar gátolja a gyermek és a környezete közötti interakciót. A zavar a beszédfejlődés bármely szakaszában felléphet. A már kialakult beszédre szintén érvényes (Gordosné, 1995) ${ }^{6}$. A beszéd és a nyelvfejlődés zavarait nem lehet közvetlenül neurológiai megbetegedéssel, a beszédmotorika zavarával, érzékszervi fogyatékossággal, az intelligencia csökkenésével vagy környezeti faktorokkal magyarázni. Receptív beszédzavarként definiálja Warnke és

\footnotetext{
$5 \quad$ Fehérné Kovács Zsuzsanna: A beszédzavarok logopédiai rehabilitációjáról, avagy milyen is a beszédfogyatékosok rehabilitációja?, Fejlesztő Pedagógia, 1. sz., 2009, 39-47.

6 Gordosné Szabó Anna: Bevezetés a gyógypedagógiába. Budapest, Nemzeti Tankönyvkiadó, 1995 .
} 
Szűcs (1996) ${ }^{7}$ a beszéd megértésének fejlődési zavarát. Egyéves gyermek környezetének neveit még nem érti, másfél évesen a gyakran előkerülő tárgyak nevét nem ismeri, két évesen egyszerü felszólításoknak nem tud eleget tenni. Később grammatikai struktúrákat nem tud elkülöníteni. Gyakran jár együtt szociális-, érzelmi- és magatartászavarral. Prognózisa viszonylag kedvezőtlen. Az iskoláskorú gyermekek 3-10\%-ánál fordul elő. Fiúknál gyakoribb. Oka lehet genetikai (családi) hajlam. Koragyermekkori strukturális és funkcionális cerebrális zavar szerepet játszhat létrejöttében. Beszédet érintő depriváció is befolyásolhatja a beszédfejlődést. Nem magyarázható pusztán neurológiai betegséggel, a beszédlefolyás zavaraival, korlátozott érzékszervi múködéssel, csökkent intelligenciával vagy nyelvi (beszéd-) deprivációval.

Differenciáldiagnózis nézőpontjából Warnke és Szűcs (1996) hangsúlyozza, hogy a beszédfunkciókat standardizált tesztmódszerekkel kell megragadni. Lényeges szempont a hallóképesség, az intelligencia nonverbális vizsgálata. A szellemi visszamaradás, a mutizmus kizárandó.

Subosits (2004) ${ }^{8}$ nélkülözhetetlennek tartja a jó és tiszta beszédpéldát, amely az úgynevezett külső hallási ingerületek formájában jut el a beszélni tanuló kisgyermek központi idegrendszerének feldolgozó központjába. A szegényes, nem megfelelő beszédkörnyezet, az érzelmileg sivár beszédpélda gyakran lehet az oka a fejlődés megkésésének. Saját hangunk meghallása - mint akusztikai önkontroll - szintén nagy jelentőségű a gyermek beszédfejlődésében és a beszéd oktatásában.

A hátrányos helyzetű tanulók nyelvhasználatára jellemző a rövidre zárt kommunikációs stratégia, jelenti ki Mészáros és Kas (2008)9 ${ }^{9}$ Nyelvhasználatuk egyszerü mondatok alkalmazására, a zsargonok (sajátos szavak) használatára szükül. Többnyire felszólító mondatokat veszik igénybe. A szavak jelentése megtapad az adott közösségben előfordultaknál. Nem észlelik az összetett mondatok tagmondatai közötti logikai vagy tartalmi kapcsolatot, nem ismerik fel az irodalmi vagy ismeretterjesztő szövegek ok - okozati összefüggéseit. Az átvitt értelemben használt kifejezések, elvont fogalmak értelmezhetetlenek számukra.

Hajdúné (2014) ${ }^{10}$ az Arany János Tehetséggondozó Program jóvoltából létrehozott mérésének egyik célja a nyelvi szintek elmaradásának, az anyanyelvi kompetencia hiányosságainak feltárása. A teszt az alábbi 10 feladatból állt: álszavak másolása; szinonimakeresés; ellentétes jelentésű szavak; hasonló hang-

\footnotetext{
7 Warnke, A., Szűcs, E.: A lelki fejlődés zavarai gyermekkorban, in Vetró Á., W. LI. Parry-Jones (szerk.): Gyermek- és Ifjúságpszichiátria orvostanhallgatók és szakorvosjelöltek számár, Szeged, GyLE Kiadó, 1996.

Subosits István: Hangtan, Budapest, TAS-11 Kft, 2004.

9 Mészáros Andrea, Kas Bence: A kognitív funkciók megismerésének szerepe a nyelvfejlődési zavar diagnosztikájában, Gyógypedagógiai Szemle, 2. sz., 2008.

${ }_{10}$ Hajdúné Csakajda Ildikó: Hátrányos helyzet = nyelvi hátrány? Nyelvi fejlesztés az Arany János Kollégiumi Program 9. előkészítő évfolyamán a hódmezővásárhelyi Németh László Gimnázium és Általános Iskolában. Letöltve 2014. 2014. 10. 26., from http://epa.oszk.hu/ooooo/ooo35/00143/ pdf/EPAoo035_upsz_2010_08-09_068-075.pdf
} 
zású szavak mondatba foglalása; összekeveredett betűkből szóalkotás, jelentés magyarázás; tőmondat bővítése megadott számú mondatrésszel; tagolatlan szöveg tagolása; hibás toldalékok, vonzatok, névelő javítása szövegben; szómagyarázat; idegen szavak mondatba illesztése. A hátrányos helyzetű tanulók nyelvi képességei valamennyi nyelvi szinten elmaradást mutatnak. Az álszavak másolásának, a hangok azonosításának és megkülönböztetésének, a hang - betü megfeleltetésnek a hibája az alsó nyelvi szint sérülésére utalhat, ezért a felsóbb nyelvi szintek (szókincs, szószerkezetek, mondatok, szöveg) ugyanúgy hibásan funkcionálnak. A szúk szókincs, a szemantikai hiányosságok nemcsak a nyelvi készséget érintik, hanem a szövegértést, szövegalkotást is.

A magyar nyelv relációs szókincsét 250-300 szó alkotja, állapítja meg Nagy (2002) ${ }^{11}$. A térre, időre, hasonlóságra, mennyiségre igekötők és toldalékok is utalnak. A relációs szavak biztonságos alkalmazása nélkül a nyelv használhatatlan. Szövegértési, szövegalkotási, matematikai problémát okoz a relációs szavak hibás alkalmazása vagy annak hiánya. Vagyis ezen anyanyelvi hiányosság okán a matematikai kompetencia talaján egyaránt hátrány, elmaradás mutatkozik.

\subsection{A korlátozott nyelvi képességek pszichés vonatkozásai}

„A korlátolt nyelvi képességek negatívan hathatnak a gyermek belső (lelki) müködésére azáltal, hogy korlátozzák a társas interakcióhoz elengedhetetlen kódolási és dekódolási lehetőségeket, ezek téves személyközi percepciót és kommunikációt eredményezhetnek" (Fehérné, 2000. 98. o.). ${ }^{\mathrm{i} . \mathrm{m}}$.

A nyelv egyik legfontosabb funkciójának Gallagher (1999) ${ }^{12}$ az intraperszonális, az emocionális és a magatartási szabályozást tartja. A korlátolt nyelvi múködések végett az érzések nem tudnak nyelvi formában kifejezésre jutni, ezáltal a kommunikációs helyzetek félreértésre adhatnak okot, negatívan hat a gyermek lelki müködésére. Az érintett területek a következők:

- a nyelvi output nem alkalmazkodik a hallgatói igényekhez,

- nehézségek lépnek fel egy adott téma megkezdésében, annak folytatásában és a témaváltásban,

- kevés pozitív szociális megnyilvánulást mutatnak az interakciójuk/társalgásuk során,

- a verbális elégtelenség, azaz a nem adekvát nyelvhasználat (a szókincs, mondattervezés) a tervezésében és a szerkesztésében is egyaránt megjelenik.

\footnotetext{
${ }^{11} \quad$ Nagy József: Relációszókincs, in Nagy József (szerk.): Az alapkészségek fejlődése 4-8 éves életkorban, Budapest, OKÉV KÁOKSZI, 2002.

${ }_{12}$ Gallgaher, T. M.: Interrelationships among children's language, behavior, and emotional problems, Topics in Language Disorders, 19 (2). sz., 1999, 1-15.
} 
A nyelvi problémákra visszavezethető emocionális és/vagy magatartási zavarok felismerése lényeges diagnosztikai feladat, amelyből terápiás következmények is fakadnak. Gyakorló szakemberként fontosnak véljük tájékoztatni a szülőket, tanárokat a nyelvi korlátozottság és az emocionális, magatartási reakciók közötti összefüggésekről.

\subsection{Differenciáldiagnózis}

Az egyéni esetek megítélésekor, később pedig a diagnosztikus protokoll összeállításakor a beszéd- és nyelvelsajátításban szerepet játszó tényezők fejlődéséről, illetve aktuális állapotukról rendelkezésre álló információk közötti összefüggések feltárása a cél. Ezen komponensek együttes számbavétele elősegíti a tünetek és okok kapcsolatának értelmezését differenciáldiagnosztikai aspektusból. (Mészáros és Kas, 2008) ${ }^{\text {и. }}$

A nyelvelsajátítást befolyásoló faktorok két nagy csoportra oszthatóak. Az ún. külső, vagyis környezeti tényezők a nyelvi minta, az input minőségét és mennyiségét jelentik. A nyelvi zavarok szempontjából legfontosabb szegmensét képezi a család szocioökonómiai státusza (socioeconomical status - SES) és annak összetétele (testvérek, születési sorrend), illetve a korai, különösen az első másfél évre jellemző gondozás minősége (többek között az otthoni nevelés vs. bölcsőde) emelhető kiemelni. Nittrouer (1996) ${ }^{13}$ jelentős elmaradást mutatott ki alacsony szocio-ökonómiai státuszú családból származó gyerekeknél a beszédészlelési stratégiák fejlődésében, a fonológiai tudatosságban és a receptív szókincsben egyaránt. Az alacsony SES nyelvi fejlődésre gyakorolt hatása közvetett; az ilyen családokra a bernsteini értelemben vett korlátozott kód - szúkebb szókincs, egyszerübb és rövidebb mondatszerkezetek, magasabb arányú névmáshasználat, zsargonjelleg -, illetve sajátos, főként imperatívuszt használó, rövidre záró kommunikációs stratégiák fordulnak elő.

Raviv és mtsai (2004) ${ }^{14}$ bebizonyították ezen feltevéseket kutatásukban. Mintegy 1000 hároméves gyerek nyelvi képességét, családjuk szocio-ökonómiai státuszát, édesanyjuk szülői érzékenységét vizsgálva azt találták, hogy az SESfaktorok és a nyelvi képesség mutatói korrelálnak a nevelkedés változóival. Vagyis az anyának a gyerekével szemben mutatott érzékenységnek és az otthoni-családi környezetnek kognitív stimuláló hatása van. Azaz, a család anyagi helyzete a gyerek neveltetési környezetének befolyásolása által rontja a hároméves kori nyelvi teljesítményeket: egyrészt gátat szab a minél sokrétúbb tapasztalatszer-

\footnotetext{
${ }_{13}$ Nittrouer, S.: The Relation Between Speech Perception and Phonemic Awareness Evidence From Low-SES Children and Children With Chronic OM, Journal of Speech and Hearing Research, 39. sz., 1996, 1059-1070.

14 Raviv, T., Kessenich, M. Morrison, F. J.(2004): A mediational model of the association between socioeconomic status and three-year-old language abilities: the role of parenting factors, Early Childhood Research Quarterly, 19, 528-547.
} 
zésnek, másrészt a bizonytalan egzisztenciális körülmények, s az ezek következményeként fellépő stressz olyan anyai viselkedésformákat alakítanak ki, amelyek a nyelvi fejlődésre nézve kedvezőtlen érzelmi légkört eredményeznek a gyerek számára. Más kísérletekből kiderült az is, hogy inkább a receptív (értő), mint az expresszív (kifejező) nyelvi képességre gyakorolnak negatív hatást (Reznick, $1997^{15}$; Murray és Hornbaker, $1997^{16}$ ).

Azt, hogy a gyermek a rendelkezésre álló nyelvi inputot miként tudja kezelni, mit képes hasznosítani, az ún. belső faktorok determinálják. A belső tényezők közül a rizikófaktorok feltárását célzó vizsgálatok a nem, a genetika, a pre, peri-, postnatális történések (pl. koraszülöttség, alacsony születési súly), a hallásállapot, a beszédmotorikum, a tanulási képesség, a neurológiai érettség és az esetlegesen előforduló pszichiátriai problémák szerepére hívja fel Kniff (2003) ${ }^{17}$ a figyelmet.

Ami a nyelvfejlődési zavar genetikáját illeti, felmerülhet a beszéd- és nyelvi zavarok családi halmozódást kérdése. Annyi bizonyos, hogy a hajlam öröklődhet. Kovac és munkatársai $(2002)^{18}$ ikerkutatásai is ezt támasztják alá, miszerint egypetéjü ikreknél 0.70 , kétpetéjüeknél pedig 0.46 a specifikus nyelvi zavar konkordanciája, vagyis annak esélye, hogy ha legalább az egyik gyermek, akkor a másik is érintett. Stromswold (2000) ${ }^{19}$ vizsgálatai demonstrálták, hogy 46\%ban a rokonoknál is szerepelt valamilyen nyelvfejlődési eltérés. Bishop (2001) ${ }^{20}$ az ikertestvérek idővel megszűnt zavarait is számításba veszi. Egypetéjű ikreknél a nyelvi zavarok 95 \%-os, míg kétpetéjúeknél csupán 45 \%-os együttjárást ábrázolt.

„A DSM-IV definíciójában helyes az a feltétel, hogy az olvasás pontosságát és a megértést is mérni kell, mégpedig standardizált tesztekkel. Ez a gyakorlat nyelvére lefordítva azt jelenti, hogy az adott írásrendszer természetétől függetlenül a pontosság a legfontosabb mutató. Transzparens ortográfiájú nyelveknél, mint amilyen a magyar, a pontosság gyakran nem jól differenciál. A DSM - kritériumok alkalmazásának jelenleg Magyarországon van egy másik akadálya is. Nincsenek ugyanis standardizált olvasási tesztek, a megértés zavarait gyakran

15 Reznick, J. S.: Intelligence, language, nature, and nurture in young twins, in Sternberg, R. J., Grigorenko, E. L. (szerk.): Intelligence, heredity, and environment, New York, Cambridge, University Press, 1997, 483-504.

16 Murray, A. D. és Hornbaker, A. V.: Maternal directive and facilitative interaction styles: Associations with language and cognitive development of low risk and high risk toddlers, Development and Psychopathology, 9. sz., 1997, 507-516.

${ }_{17}$ Kniff, W. A.: Diagnostics in children with language problems: Differences between a multidisciplinary and monodisciplinary procedure., Groningen, Ph.D. thesis, Rijks University, 2003.

${ }_{18}$ Kovac, I., Gopnik, M. és Palmour, R. M.: Sibling Resemblance for Specific Components of Linguistic Competence in Families of Speech/Language Impaired Children, Journal of Neurolingustics, 15, 2002, 497-513.

19 Stromswold, K.: Cognitive and neural aspects of language acquisition., in Lepore, E., Pylyshyn, Z. (szerk.): What is cognitive science? Oxford, Blackwell, 1999, 356-400.

${ }_{20}$ Bishop, D. V. M.: Uncommon understanding. Development and Disorders of Language Comprehension in children, Psychology Press, 1997, 19-49. 
esetlegesen kialakított, normatív adatokkal nem rendelkező feladatokkal mérik" (Csépe, 2006. 105. o.). ${ }^{21}$

Costard (2007) ${ }^{22}$ ugyanezen állásponton van, miszerint a gyakorlati diagnózist nehezíti, hogy nem állnak rendelkezésre formális (standardizált) olvasási és helyesírási diagnosztikus eljárások, amelyek az életkorhoz vagy az olvasási, írási korhoz viszonyítanák az elmaradást, illetve a jelentős (szignifikáns) elmaradást értelmezni tudnánk. Hozzáfüzi, hogy a különböző időpontokban elvégzett vizsgálatok nem adnak azonos eredményt ugyanazoknál a gyermekeknél.

Lőrik (2014) ${ }^{23}$ további problémára hívja fel a figyelmet. Nincs ugyanis egységesen elfogadott nézet a tekintetben, hogy melyik osztályfokban releváns a diszlexia megállapításáról döntést hozni. A gyakorlat azt prezentálja felénk, hogy legkorábban a második osztály első felének végén lehet megállapítani, amikor a gyermek fejlődésében olyan szakaszba érkezett, amelyben különleges segítségre van szüksége. Hangsúlyozza a különböző területeken dolgozó specialisták közös munkáját. A fül-orr-gégész, foniáter, audiológus, szemész, neurológus, klinikai pszichológus, gyógypedagógiai pszichológus, kognitív (neuro) pszichológus, logopédus, tanító és más szakemberek együttmüködése vezethet véleménye szerint eredményre.

\section{MÓDSZER}

\subsection{A vizsgálat körülményei}

A vizsgálatokat X., illetve XIX. kerületi intézményekben végeztem, ahol az intézményvezetők és osztályfőnökök nyitottan és készségesen álltak hozzá. Eredeti elképzelés szerint a fejlődési diszlexiás gyermekeket szerettem volna öszszehasonlítani a kontroll csoporttal, mivel a következtetések és az eredmények értelmezése nagymértékben függ a kontrollcsoport kiválasztásától, ezért a megfelelő mutatón történő illesztés alapvető fontosságú. Azt kívántam feltárni, mér-e a két teszt 8-12 éveseknél is. Amikor azonban a nem fejlődési diszlexiásokkal kezdtem el felvenni a próbákat, meglepően szélsőséges eredmények születtek a Piramis és Pálma teszt során. Pedagógusokkal való konzultálás vezetett rá arra, hogy mennyire számottevő a család szocio-ökonómiai helyzete. Tovább vizsgálódva, fokozatosan nőni láttam a differenciákat. Végül 3 csoport értékét vetettem össze.

\footnotetext{
${ }^{21} \quad$ Csépe Valéria: Az olvasó agy, Budapest, Akadémiai Kiadó, 2006.

${ }_{22}$ Costard, S.: Störungen der Schriftsprache. Modellgeleitete Diagnostik und Therapie, Stuttgart, G. Thieme Verlag, 2007.

${ }^{23}$ Lőrik József: Az írott nyelv zavarai, a diszlexia és a diszgráfia. Letöltve 2014. 10. 26., from http:// www.mlszsz.hu/files/Az\%20\%C3\%ADrott\%20nyelv\%20zavarai.pdf
} 
A vizsgálatra a fejlesztő szobában került sor, ami a fejlődési diszlexiás gyerekeknek ismerős volt, ugyanakkor megnyugtatóan hatott a szoba berendezése a kontroll csoporthoz tartozó gyermekekre is.

\subsection{Vizsgálati személyek}

A fejlődési diszlexia megállapításához részben a BNO-10 és DSM-IV diagnosztikai kritériumaira támaszkodtam, amely kimondja, hogy ki kell zárni a perifériás és centrális hallás-, látás- és mozgászavart, a mentális alulteljesítést, a figyelemzavart, az auditív feldolgozás zavarát (Central Auditory Processing Disorders), valamint a szerzett zavarokat és egyéb tényezőket. További kritériumként határoztam meg a dadogás beszédkórképet, az autizmus spektrum zavart, a mutizmust, valamint a beszéddeprivációt.

9 évesek voltak a legtöbben (45-en). Visszautalnék itt Warnke és Szűcs (1996) azon megállapítására, hogy a fiúk érintettebbek a nyelvfejlődési zavarban. Az én mintámban is három eset kivételével (szociálisan hátrányos helyzetű 8 éveseknél fordított az arány, a szociálisan hátrányos helyzetű 10 és 11 éveseknél pedig kiegyenlített) a lányok alkották úgymond a „kisebbséget”, ők voltak kevesebben.

\subsection{Vizsgálati módszerek}

A fent említett kritériumok alapján kiválasztottam 50 fejlődési diszlexiás, 50 hátrányos helyzetű, 50 kontroll gyermeket a 8-12 éves korosztályból. Az előbbi 2 csoport a X. kerületi általános iskolák növendékei, a harmadik a XIX. kerületi intézmények tanulói.

Gósytól (1995/2006) tudjuk, hogy a fonématudatosság több területét is befolyásolja a beszédhangdriszkimináció, ami csak az olvasástanulás időszakában (7-8 éves korban) érik be teljesen. Ebből kiindulva határoztam meg a 8 évet a tartomány egyik végpontjaként, amikorra már az olvasás- és íráselsajátítás megtörténik. Másik végpont 12 évre esett, a tinédzser kor előtti periódusra.

Vizsgálatomhoz két klinikai neuropszichológiában használatos, még magyar sztenderddel nem bíró tesztet választottam, amellyel kísérletet teszek arra, hogy mérnek-e gyermekeknél is. Eddig ilyen kutatás nem létezett. A felnőttekkel végzett tanulmányok tanulságairól is pusztán csekély pszichometriai információról tájékoztatnak a szakirodalmak.

A Piramis és Pálma teszt (PPT) (Howard és Patterson, 1992) ${ }^{24}$ a szemantikus emlékezet vizsgálatára szolgál: tényekre, általános tudásra, szó jelentésére vo-

24 Howard, D. és Patterson, K.: Pyramids and Palm Trees: A test of semantic access from pictures and words, UK, Bury St. Edmunds, Thames Valley Test Company, 1992. 
natkozóan. Nem kontextuális memória, független az információ kódolásának helyétől és idejétől. Egyetlen instrukciót kap a vizsgálat személy: „Melyik alsó kép illik a legjobban a felső képhez?"

A Kempler-féle teszt (Kempler, 1986) ${ }^{25}$ : az eltérő mondattípusok feldolgozásán alapul, a megértést „nézi” meg közelebbről. Ekkor a „Mutasd meg azt a képet, amelyikről mesélek!” utasítás hangzik el.

\section{EREDMÉNYEK}

\subsection{Csoportonkénti összehasonlítás}

A tesztekben legtöbb hibát a fejlődési diszlexiások vétettek (a Piramis és Pálma teszt hibaátlaga 6,66, a Kempler-teszté 2,72). Az első feladatsorban a legtöbb hiba 22, míg a másodiknál 15 volt. Az átlagtól való átlagos eltérés a Piramis és Pálma tesztben nagyobb (3,514), mint a mondatmegértés mérésénél $(2,807)$. Az asszociációs képesség területén a szociálisan hátrányos helyzetúek átlaga volt a legmagasabb $(5,78)$, ami statisztikai szempontból nem jelent szignifikáns eltérést a fejlődési diszlexiás csoport eredményeihez képest. Hasonlóan alakult a szemantikus feldolgozás. A szociálisan hátrányos helyzetű csoport általánosan jobban teljesített $(1,98)$, mint a fejlődési diszlexiás csoport, de itt sem szignifikáns az eltérés. A szórás a diszlexiás csoporthoz képest mindkét tesztben magasabb (3,94 és 3,02). A hátrányos helyzetúek csoportjában a Piramis és Pálma tesztben 19, a Kempler-félében pedig 13 a maximális hibaszám.

A kontroll csoport szinte hibátlanul megoldotta a Kempler-féle tesztet (átlag 0,3). A Piramis és Pálma feladatokat a másik két csoporthoz képest kevesebb hibával $(2,14)$ teljesítették. Jelentéktelennek mondható az átlagtól való eltérésük (1,959 és 0,763); maximum 8, illetve 4 alkalommal döntöttek helytelenül.

Megállapítható tehát, hogy a fejlődési diszlexiásoknál és a szociálisan hátrányos helyzetűeknél jóval nagyobb a csoporttagok teljesítményének változása, több a kiugró érték, egyéni különbség; ellentétben a homogénebben teljesítő kontrollcsoporttal.

\section{2. Életkoronkénti összehasonlítás}

A Piramis és Pálma tesztben általánosan magasabb a hibázások száma (186, 243, 123, 92, 77), ami nem meglepő, hiszen 52 részpróbát foglal magában, míg a Kempler-féle $(65,98,46,13,23)$ csak 24-et. Érdekes módon, nem a legfiatalabbak, hanem a 9 évesek érték el a leggyengébb teljesítményt (összesen 243-szor

${ }_{25}$ Kempler, D.: The Kempler Comprehension Task. Copyright, 1986. 
tévedtek az egyikben és 98-szor a másikban). Kiemelnénk ezen belül a szociálisan hátrányos helyzetü gyermekek csoportját, akik ebben az életkorban a fejlődési diszlexiásokhoz képest többször hibáztak (82 és 30 vs. 140 és 65). Ez a tendencia a Piramis és Pálma esetében már a 8. életévüket betöltötteknél is megfigyelhető. Fejlődési diszlexiásoknál ebben az életkorban 71 téves döntés született, a szociálisan hátrányos helyzetűek viszont csak 91 hibát ejtettek. Az „idősebbeknél” már nem volt jelentősebb differencia.

\subsection{Tesztfeladatonkénti összehasonlítás}

Megfigyeltük, mely képeknél született a legtöbb hibázás. A Piramis és Pálma tesztben a 16. lapon szélmalomhoz társítható nárcisz, illetve tulipán képe szerepel32. A fejlődési diszlexiások közül 41-en előbbi lehetőség mellett döntöttek, a szociálisan hátrányos helyzetűek 38-szor választották, míg a kontroll csoport 34-szer. A diszlexiás csoportnak 21 esetben problémát okozott a 40-es számmal jelölt próba során a disznó/szamár asszociálása a makkhoz. A hátrányos helyzetű csoport 11-szer mutatott a helytelen képre, a kontroll csupán 4-szer.

Két tesztfeladat különösen a szociálisan hátrányos helyzetű gyermekeknek okozott problémát, de a többi gyermek számára is nehezen érthető volt. A 16. feladatnál a szélmalom és a nárcisz társítása Hollandia kultúrájának ismerete alapján meglehetősen nehéz volt, különösen a hátrányos helyzetű gyermekek számára. Az 51. feladat kapcsán átgondolandó, hogy az iskolapadok napjainkban már nem a rajz ábrázolásának megfelelően néznek ki. A jövendő vizsgálatokban felmerül e két tesztfeladat módosításának vagy kihagyásának lehetősége.

Az 51-es feladatnál a fejlődési diszlexiások 26 alkalommal nem tudták megítélni, a táblához asztal vagy iskolapad illik-e jobban. Ez a hátrányos helyzetű csoport tagjainak 20 esetben jelentett gondot, a kontrollnak pedig 14-szer. Húsz szociálisan hátrányos helyzetú tanuló számára nem volt egyértelmủ a 39. feladatnál, hogy a biztosítótủ a kislányhoz vagy a csecsemőhöz tartozik. Ez a bizonytalanság a fejlődési diszlexiásoknál 16-szor fordult elő, míg a kontrollnál egyszer sem. Az eszkimó és kenu párosítása ugyancsak a szociálisan hátrányos helyzetűeknek volt a legnehezebb, 27 főnek. A fejlődési diszlexiások köréből 20an, míg a kontrollcsoportból heten hibáztak.

A Kempler-féle tesztben eltérő mondatok megértése jelentett nehézséget a három csoport számára. A diszlexiás csoport a legtöbbször (17 esetben) „A fiút megcsókolja a lány." kijelentés után határozta el magát a hibás illusztráció mellett. „A kutyát kergeti a macska.” értelmezése 16-szor volt helytelen. Tizenegy esetben „A kutya megharapja a macskát, aki megharapja a lányt.” mondat hívott elő téves választ. A fejlődési diszlexiások a tárgy, állítmány, alany (OVS) felépítésű, valamint a beágyazott tárgyi mellékmondat megértésében hibáztak a leggyakrabban. A hátrányos helyzetű csoportban 11 tanuló nem ismerte fel a 
tárgy, állítmány, alany (OVS) felépítésű, „Az anyát húzza a gyerek.” kijelentést. A 19. mondat („A kutya megharapja a macskát, aki megharapja a lányt.”) 11-szer eredményezett tévedést. Egy másik beágyazott tárgyi mellékmondat megértése („A macska, amely megrúgja a fiút, megrúgja a kutyát.) hét esetben okozott problémát. A kontrollcsoport hibái 0 és 2 pont között mozogtak. Meglepő módon, „A fiú ellöki a lányt.” mondatnál is kétszer fordult elő tévedés. „A medve figyeli a férfit és a fiút." mondatot 2 diák értelmezte félre.

A Korrigált rang Welch-próba a következő eredményt adta: $\operatorname{rW3}(2 ; 90,0)=$ $46,733(\mathrm{p}=0,0000)^{* * * *}$. Leszögezhető, hogy a 2. és 3., illetve az 1 . és 3 . csoportok között van szignifikáns eltérés a Piramis és Pálma tesztet illetően. a fejlődési diszlexiások és a szociálisan hátrányos helyzetűek PPT-ben elért teljesítményeiben nincs szignifikáns különbség.

1. táblázat. A három csoport összehasonlítása a Piramis és Pálma, illetve Kempler-tesztben

1. csoport: Fejlődési diszlexia; 2. csoport: Hátrányos helyzetűek; 3. csoport: Kontroll

\begin{tabular}{lll}
\hline $\begin{array}{l}\text { Páronkénti sztochasztikus } \\
\text { egyenlöség tesztelése }\end{array}$ & Szignifikancia szint \\
\hline$A(1,2)=0,580 \mathrm{BM}(85,7)=1,367$ & $\begin{array}{l}(p=0,17) \\
(p=0,00)\end{array}$ & $\begin{array}{l}\text { Bonferroni szignif.: } p=0,52 \\
\text { Bonferroni szignif.: } p=0,00^{* * *}\end{array}$ \\
$\mathrm{~A}(1,3)=0,890 \mathrm{BM}(90,6)=12,069$ & $(p=0,00)$ & Bonferroni szignif.: $p=0,00^{* * *}$ \\
$\mathrm{~A}(2,3)=0,797 \mathrm{BM}(86,5)=6,722$ & Kempler teszt & \\
\hline & & Szignifikancia szint \\
Páronkénti sztochasztikus & & \\
egyenlöség tesztelése & $(p=0,02)$ & Bonferroni szignif.: $p=0,05+$ \\
$A(1,2)=0,634 \mathrm{BM}(94,4)=2,420$ & $(p=0,00)$ & Bonferroni szignif.: $p=0,00^{* * *}$ \\
$A(1,3)=0,844 \mathrm{BM}(81,1)=9,273$ & $(p=0,00)$ & Bonferroni szignif.: $p=0,00^{* * *}$ \\
$A(2,3)=0,710 \mathrm{BM}(78,8)=4,728$ & &
\end{tabular}

Az 1. táblázatban feltüntetett értékek azt mutatják, hogy a fejlődési diszlexiások és a szociálisan hátrányos helyzetűek Piramis és Pálma tesztben elért teljesítményében nincs szignifikáns különbség. A második sor mutatói arra engednek következtetni, hogy a fejlődési diszlexiások és a kontroll csoport teljesítménye szignifikánsan eltér. A szociálisan hátrányos helyzetű gyermekek eredménye szintén szignifikánsan különbözik a kontroll csoportétól. A fejlődési diszlexiások és a szociálisan hátrányos helyzetűek a Kempler-féle tesztben nyújtott teljesítménye hasonlóan alakul, azonban a kontroll csoport teljesítményétől különböznek.

Látható tehát, hogy a Piramis és Pálma, valamint a Kempler-féle teszt eredeti célcsoportja (afázia, vizuális agnózia, Alzheimer-kór mint szemantikus emlékezeti deficit) mellett a 8-12 éves korú gyermekek vizsgálatára is alkalmas, 
hiszen a fejlődési diszlexiás és kontroll csoport eredményei szignifikánsan különböznek. Az eredmények egyértelmúen prezentálják a nyelvi fejlődési zavart, az asszociációs képességek, mondatmegértés, szemantikus emlékezet fejlettségében mutatkozó elmaradást

\section{DISZKUSSZIÓ}

A fejlődési diszlexia komplex tünetegyüttes, melyben kulturális hatások is szerepet játszanak. A specifikus (akusztikai/fonológiai) feldolgozási képességek összefüggnek a nyelvi fejlődéssel. Mindezek vonatkozásában erős a genetikai determináltság, de lényeges szerep jut a környezetnek is. A nyelv elsajátításának biológiai és pszichés feltételei mellett az optimális környezet társadalmi, szociokulturális követelmény, befolyásolja a beszédminta minőségét és mennyiségét. Ez az elvárás egyre jobban sérül, például az életmódban bekövetkezett változások, a városiasodás következtében. (A gyermekek ma már nem érintkeznek a vidéki élet mindennapjainak szereplőivel, például a háziállatokkal, virágokkal, szerszámokkal.) A mozgásigény korlátozása, a mozgásos tevékenységek hiánya hatással van a nyelvfejlődésre, ahogy a vizuális kultúra túltengése is. Bizonyos agyterületek gyengébben aktiválódnak, ezáltal a kreativitás is kevésbé fejlődik. Az aktív és passzív szókincs leszúkül, a verbalitást felváltja a személytelen kommunikáció.

Az iskola teljesítménycentrikussága, a módszerek életkori sajátosságokhoz és egyéni fejlődési tempóhoz való igazodásának hiánya nem kedvez a szociálisan hátrányos helyzetủ gyermekeknek. A gyakorlási idő csökken, így a tanultak nem automatizálódnak. A szociálisan hátrányos helyzetü gyermekek, noha beleolvadnak az átlagosak csoportjába, azoktól jelentősen eltérően teljesítenek. Ma már nemcsak a fejlődési diszlexiás gyermekek esetében kell deficittel számolnunk és foglalkoznunk, hanem a szociálisan hátrányos helyzetü gyermekeknek is érdemes volna nagyobb figyelmet szentelni. A családon belüli verbális kommunikáció szűkülése, a napi mesélés hiánya a szókincs, a nyelvi rendszer elmaradását vonja maga után. A vizsgálatunkban résztvevő gyerekek kulturális hátránya, a szegénység és az élményhiány nyelvi, múveltségi hátrányként jelentkezett.

A fejlődési diszlexiásoknak joguk van a differenciált oktatáshoz, felmentést kaphatnak a szóbeli és/vagy írásbeli számonkérés alól, és több időt kaphatnak a feladataik teljesítéséhez. A szociálisan hátrányos helyzetűekre viszont az általános mérce érvényes. Ha szem előtt tartanánk a náluk is esetlegesen fellépő nyelvfejlődési elmaradásokat és a szocioökonómiai helyzetükből adódó hátrányokat, felzárkóztatásukkal hozzásegíthetnénk őket a tanulmányi sikerekhez.

A bemutatott vizsgálat egyik célja az volt, hogy felhívja a figyelmet arra, hogy a nyelvi fejlődési zavar jelenségköre korántsem szúkíthető a beszéd-, illetve nyelvi képességek elmaradására. A deficittel együtt járó nem nyelvi kognitív hiányok felderítésének jelentősége esszenciális. 
Eredményeink természetesen nem mechanikusak, a hibák száma alapján egy-egy gyermekről nem vonható le azonnali következtetés. A két teszt mégis kimutatja, hogy egyes képességterületeken, feldolgozási módokban milyen szintü teljesítményt nyújtanak. Lényeges kiemelni a felvétel alatt tapasztalt reakciókat, a diák korábbi produktivitását, aktuális állapotát, és a pontszámokat ezek együttes figyelembe vételével kell értelmezni. A gyakorlatot tekintve mérvadóak a differenciáldiagnosztikai és terápiás szempontok, amelyek összefoglalják a verbális és nonverbális képességek disszociációját, a fellépő kognitív zavarok társult jellegét és okát, illetve a nyelvi zavar specifikusságának felismerését és fejlesztését. Miután a fent említettek feltérképezése megtörtént, tekintetbe kell venni azt is, hogy a kognitív képességek megsegítése milyen mechanizmusokon keresztül facilitálja a nyelvi képességek elmaradott területeit.

Az általunk alkalmazott két szűrőeljárás elsődleges előnye - az intelligencia tesztekkel ellentétben -, hogy gyorsan felvehetők, feldolgozhatók, könnyen értékelhetők és mobilizálhatók; motiválják a gyermekeket, így más tesztek kiegészítőjeként is kiválóan megállják a helyüket. A vizsgált gyerekek kivétel nélkül élvezték a tesztszituációt, magával ragadta őket a vizualitás. A Kempler-féle tesztben az abszurditás mosolyt csalt az arcukra (Pl. „A fiú és a lány viszi a medvét.”) Kitartásuk, tűrőképességük, figyelemkoncentrációs képességük a mért sajátosságokon túlmenően is kiválóan követhető volt. A kontrollcsoport tagjainak különösen beindult a fantáziája, esetenként saját élményeket is meséltek; távozáskor pedig őszintén kinyilvánították tetszésüket és boldogan újságolták a pedagógusoknak, milyen feladatokat hajtottak végre.

\section{IRODALOMJEGYZÉK}

BISHOP, D. V. M.: Uncommon understanding. Development and Disorders of Language Comprehension in children, Psychology Press, 1997, 19-49.

CSÉP VALÉRIA: Az olvasó agy. Budapest, Akadémiai Kiadó, 2006.

COSTARD, S.: Störungen der Schriftsprache. Modellgeleitete Diagnostik und Therapie. G. Stuttgart, Thieme Verlag, 2007.

FEHÉRNÉ KOVÁCS ZSUZSANNA: Nyelvi képességek és a tanulási zavar, Beszédgyógyítás, 1. sz., 1998, 38-41.

FEHÉRNÉ KOVÁCS ZSUZSANNA: A nyelvi fejlődés zavaráról új megközelítésben, A pedagógus személyisége, Országos Szakmai Konferencia, VI. Soproni Logopédiai és Pedagógiai Napok, 2000, 96-104.

FEHÉRNÉ KOVÁCS ZSUZSANNA: A beszédzavarok logopédiai rehabilitációjáról, avagy milyen is a beszédfogyatékosok rehabilitációja?, Fejlesztő Pedagógia, 2009, 1. sz. 39-47.

GALLAGHER, T. M.: Interrelationships among children's language, behavior, and emotional problems. Topics in Language Disorders, 1999, 19 (2). sz. 1-15. 
GORDOSNÉ SZABÓ ANNA: Bevezetés a gyógypedagógiába. Budapest, Nemzeti Tankönyvkiadó, 1995.

GÓSY MÁRIA: GMP-Diagnosztika. A beszédészlelés és a beszédmegértés folyamatának vizsgálata. Budapest, Nikol Kkt, 1995/2006.

GÓSY MÁRIA: Gyermekek anyanyelvi kompetenciájáról, Gyógypedagógiai Szemle, 2009, 2-3. sz.

HOWARD, D., PATTERSON, K.: Pyramids and Palm Trees: A test of semantic access from pictures and words. UK, Bury St. Edmunds, Thames Valley Test Company, 1992.

HAJDÚNÉ CSAKAJDA ILDIKÓ: Hátrányos helyzet = nyelvi hátrány? Nyelvi fejlesztés az Arany János Kollégiumi Program 9. előkészítő évfolyamán a hódmezővásárhelyi Németh László Gimnázium és Általános Iskolában. Letöltve 2014. 2014. 10. 26., from http://epa.oszk.hu/00000/00035/ 00143/pdf/EPA00035_upsz_2010_08-09_068-075.pdf.

KEMPLER, D.: The Kempler Comprehension Task. Copyright, 1986.

LŐRIK JÓZSEF: Az írott nyelv zavarai, a diszlexia és a diszgráfia. Letöltve 2014. 10. 26., from http:// www.mlszsz.hu/files/Az\%20\%C3\%ADrott\%20nyelv\%20zavarai.pdf.

KNIFF, W. A.: Diagnostics in children with language problems: Differences between a multidisciplinary and monodisciplinary procedure. Groningen, Ph.D. thesis, Rijks University, 2003.

KOVAC, I., GOPNIK, M., PALMOUR, R. M: Sibling Resemblance for Specific Components of Linguistic Competence in Families of Speech/Language Impaired Children, Journal of Neurolingustics, 2002, 15, 497-513.

MÉSZÁROS ANDREA, KAS BENCE: A kognitív funkciók megismerésének szerepe a nyelvfejlődési zavar diagnosztikájában. Gyógypedagógiai Szemle, 2008, 2. sz.

MURRAY, A. D., HORNBAKER, A. V.: Maternal directive and facilitative interaction styles: Associations with language and cognitive development of low risk and high risk toddlers, Development and Psychopathology, 1997, 9. sz. 507-516.

NiTTROUER, S.: The Relation Between Speech Perception and Phonemic Awareness Evidence From Low-SES Children and Children With Chronic OM, Journal of Speech and Hearing Research, 1996, 39. sz. 1059-1070.

PLÉH CSABA: A mondatmegértés és a nyelvi szerkezet összefüggései a magyarban.

Nyelvtudományi Közlemények, 1989, 90/1-2. sz. 1-19., 19-45.

RAVIV, T., KESSENICH, M., MORRISON, F. J.: A mediational model of the association between socioeconomic status and three-year-old language abilities: the role of parenting factors, Early Childhood Research Quarterly, 19, 2004, 528-547.

REZNICK, J. S.: Intelligence, language, nature, and nurture in young twins. In Sternberg, R. J., Grigorenko, E. L. (szerk.): Intelligence, heredity, and environment. Cambridge, New York, University Press, New York, 483-504, 1997.

STROMSWOLD, K.: Cognitive and neural aspects of language acquisition. In: Lepore, E., Pylyshyn, Z. (szerk.): What is cognitive science? Oxford, Blackwell, 356-400, 1999.

WARNEK, A., SZƯCS, E.: A lelki fejlődés zavarai gyermekkorban. In: Vetró Á., W. LI. Parry-Jones (szerk.): Gyermek- és Ifjúságpszichiátria orvostanhallgatók és szakorvosjelöltek számára. Szeged, GyLE Kiadó, 1996. 